\title{
Radikalisme Islam dan Pergerakannya di Media Sosial
}

DOI 10.18196/AIIJIS.2015. 0050. 240-259

\section{NAFI' MUTHOHIRIN}

UIN Syarif Hiddayatullah Jakarta

nafi_m@yahoo.co.id

\section{ABSTRACT}

This article examines the rise of Islamic radicalism expressed through the virtual network (social media. Facebook, YouTube, Twitter, Tumbler, and other free application providers such as WhatsApp have become a spot for propaganda, recruitment, training, preparing, and calling for the establishment of Islamic Khilafa. Contemporary strategy has been used by the "defenders of Islam" to influence Muslim society. In particular, the radical groups have actively used social media to target youth as the main users of social media. (netizen). This research focuses on Islamic fundamentalism, represented by radical groups such as Hizbut Tahrir Indonesia (HTI), Harakah Tarbiyah dan Jamaah Salafi.

Keywords: radicalism; Islam; social media; youth

\section{ABSTRAK}

Artikel ini membahas tentang keriuhan gerakan radikalisme Islam yang menyeruak di jejaring virtual. Facebook, YouTube, Twitter, Tumbler, dan layanan aplikasi gratis seperti WhatsApp telah menjadi ruang bagi cara baru untuk melakukan propaganda, perekrutan, pelatihan, perencanaan, ajakan pendirian Khilafah Islam. Strategi kekinian yang terus dipraktikkan "para pembela Islam” tersebut mempengruhi cara berfikir masyarakat Muslim. Mereka secara aktif menggunakan media sosial dengan menarget anak-anak muda sebagai mayoritas warga di jejaring sosial (netizen). Penelitian ini fokus pada kelompok radikalisme Islam, termasuk beberapa organisasi fundamentalisme Islam seperti Hizbut Tahrir Indonesia (HTI), Harakah Tarbiyah dan Jamaah Salafi.

Kata Kunci: Radikalisme, Islam, Media Sosial, dan Anak Muda

\section{Radikalisme Islam di Indonesia}

Lebih dari dua dekade terakhir, khususnya di Indonesia, gerakan radikalisme Islam semakin menyeruak di ruang publik. Beberapa fenomena yang bisa dengan mudah menjadi tanda bagi kemunculannya, ialah; Pertama, aksi-aksi terorisme, baik yang berskala kecil maupun besar, terjadi secara berulang- 
ulang. Kelompok teroris bermunculan, meski berbagai langkah pencegahan dan pemberantasan telah dilakukan pemerintah. Ibarat sebuah pepatah "mati satu tumbuh seribu", kematian ideolog teroris seperti Azahari bin Husin, Amrozi, dan Imam Samudra tidak membuat pergerakan "para pejuang di jalan Allah" ini berhenti, tetapi justru bertransformasi menjadi kelompokkelompok kecil yang baru, militan, aktif, dan berbahaya.

Kedua, munculnya kelompok yang menyuarakan dikembalikannya Piagam Jakarta sebagai dasar negara. Fenomena ini menguat dan ditandai dengan dipraktikkannya bentuk pemerintahan daerah (Perda) berbasiskan Syari'ah sebagaimana yang terjadi di Sulawesi Selatan, Nanggroe Aceh Darussalam, Jawa Barat, Banten, Indramayu, Riau, Sumatera Barat, Yogyakarta, Pamekasan, dan sejumlah kota dan daerah lainnya. ${ }^{1}$

Ketiga, dijadikannya masjid, mushallah, kampus, dan kos-kos mahasiswa sebagai basis pergerakan sejumlah organisasi fundamentalisme Islam. Tempattampat ini menjadi pusat kajian, indoktrinasi, perekrutan dan mobilisasi benihbenih Islam radikal melalui program halaqah, usrah, atau daurah. ${ }^{2}$ Keempat, hadirnya beberapa organisasi lokal (tidak ada kaitannya dengan gerakan Islam transnasional) yang mengatasnamakan Islam, seperti Front Pembela Islam (FPI), Majelis Mujahidin Indonesia (MMI), dan Forum Umat Islam (FUI) yang menginginkan diberlakukannya islamisasi ruang publik, serta menjadi "aparat keamanan" bagi masyarakat yang melanggar "norma-norma agama" dalam perspektif mereka.

Kelima, menguatnya gerakan radikalisme Islam juga ditengarai oleh keberadaan laman, akun di media sosial, portal online, serta penerbitan-penerbitan berbasis Islam yang sengaja dibuat untuk memprogandakan ideologiideologi kekerasan, ujaran kebencian, pendirian negara Islam, dan hujatan terhadap produk-produk yang berasal dari Barat.

Di era kekinian seperti sekarang ini, tidak dapat dipungkiri bahwa mengemukanya gerakan radikalisme dan terorisme, lebih didominasi oleh gejala fenomena yang paling akhir. Khamami Zada menjelaskan, bahwa sebagian buku, majalah dan portal online Islam berasimilasi dengan organisasi keagamaan atau individu dengan faham keislaman yang berorientasi radikal. ${ }^{3}$ Kemunculan portal-portal online dan penerbitan-penerbitan berbau radikal menjadi tren baru bagi gejolak pemahaman keagamaan radikal di Indonesia. Sebut saja misalnya, Al-Wa'i (tabloid yang dimiliki dan dikelola Hizbut Tahrir Indonesia), Pustaka At-Taqwa (dimiliki oleh Abu Salam, seorang Salafi), dan Jazeerah Solo (penerbit yang menerbitkan buku Imam Samudra 'Aku Melawan 
Teroris'). Majalah, buku, dan portal online Islam ini tidak semata memiliki motivasi untuk kepentingan bisnis, tetapi bertujuan mendesiminasikan fahamfaham keagamaan tertentu. Bahkan, untuk penerbit-penerbit buku Islam menyelenggarakan Islamic Book Fair dalam beberapa tahun ini. Agenda ini memiliki maksud dan tujuan yang jelas untuk memasarkan buku-buku Islam radikal.

Fakta-fakta tersebut memperjelas kondisi keberagamaan umat Islam di Indonesia yang semakin kritis. Selain hampir setiap hari, publik dipertontonkan dengan aksi-aksi pemberantasan teroris oleh Densus 88, masyarakat juga terus diserang kekhawatiran terhadap masa depan generasi muda yang sangat mungkin akan terinfiltrasi pemikiran-pemikiran keagamaan yang keras, konservatif, kaku, dan menakutkan. Terlebih, seperti disebutkan sebelumnya, bahwa pola, strategi, dan pergerakan berbagai kelompok radikal Islam dalam rangka menyebarluaskan pemahaman keagamaannya itu telah menyergap ke setiap penjuru. Bahkan, tempat ibadah seperti masjid dan mushallah, terkooptasi dengan ajaran-ajaran yang keluar dari doktrin Islam.

Jika dirunut ke belakang, sesungguhnya meningkatnya aktivitas keagamaan yang ditengarai berbau radikal Islam seperti ini, mulai marak sejak tumbangnya Orde Baru yang ditandai dengan lengsernya rezim otoritarian Soeharto (1998). Orde Baru jatuh, lalu diganti dengan era reformasi sebagaimana yang dicitacitakan semua elemen bangsa. Babak baru ini ditandai dengan dibukanya kran demokrasi yang selebar-lebarnya. Dengan harapan yang sangat kuat, Indonesia akan menjadi negara yang maju, masyarakatnya hidup sejahtera, berkecukupan secara ekonomi, dan hak-hak warga dapat terpenuhi.

Namun, siapa yang menyangka bila babak baru itu tidak mampu dikelola secara baik dan bersih, sehingga reformasi yang semula mencita-citakan keadilan, malah memunculkan ketimpangan. Di pihak lain, tidak kokohnya pedoman demokrasi yang dianut membuat negeri ini kecolongan dengan masuknya berbagai ideologi yang bersumber dari bangsa lain. Ironisnya, ideologi transnasional tersebut membuat anak bangsa tercerabut dari rasa memiliki bangsa ini.

Reformasi menjadi babak baru bagi kemunculan gelombang radikalisme Islam dan terorisme yang lebih besar. Tidak kokohnya demokrasi membuat berbagai ideologi dari luar berinfiltrasi secara sistematis di Indonesia. Di lain pihak, berbagai kelompok radikal yang mulanya bergerak secara sembunyisembunyi, seperti HTI dan Harakah Tarbiyah, melihat kesempatan ini lalu bergerak secara multisel dan menguatkan keberadaannya di berbagai tempat 
dan situasi, tak terkecuali di sektor politik praktis.

Berbagai ideologi dan gerakan Islam radikal berebut pengaruh dengan melakukan indoktrinasi dan menjaring keanggotaan dalam jumlah besar. Dalam hal ini, HTI dan Tarbiyah adalah dua organisasi Islam transnasional yang paling mendapat keuntungan dari jatuhnya Soeharto. ${ }^{4}$ Sementara pertumbuhan Jamaah Salafi berjalan konstan karena pergerakannya tidak mengambil jalan politik praktis.

Dapat dikatakan bahwa tidak ada diskursus keagamaan yang patut menjadi perbincangan menarik pasca tumbangnya Orde Baru kecuali maraknya kemunculan gerakan radikalisme dan terosisme. Hal ini terutama karena beberapa gerakan Islam yang datang belakangan ini menunjukkan pola keberagamaan yang berbeda sebagaimana yang dipraktikkan Muhammadiyah dan Nahdlatul Ulama. Kelompok radikal Islam bersimpul pada perjuangan politik Islam, mendirikan Khilafah Islam, serta menolak demokrasi dan Pancasila sebagai sistem pemerintahan nasional, sementara Muhammadiyah dan NU mempopulerkan Islam toleran dan terbuka terhadap pokok-pokok pikirian modern.

Padahal, ketika rezim Orde Baru berkuasa (1966-1998), kata "radikalisme" dan "terorisme" yang ditujukan kepada kelompok tertentu, hampir tidak pernah keluar ke permukaan, apalagi menjadi pembicaraan dalam waktu yang lama di media massa. ${ }^{5}$ Penyebutan atas kasus kekerasan yang dimotori oleh kelompok yang berbasiskan keagamaan saat itu, lebih dikatakan sebagai gerakan pemberontakan. Hal tersebut tercermin, misalnya yang terjadi pada pemberontakan di Aceh dan Papua. Akan tetapi, ditandai dengan bangkitnya Reformasi, tepatnya pasca meledaknya serangkaian aksi pengeboman oleh kelompok teroris pada tahun 2000, seperti Bom Kedubes Filipina (1/8), ${ }^{6}$ Bom Kedubes Malaysia (27/8), ${ }^{7}$ Bom Bursa Efek Jakarta (13/9), ${ }^{8}$ dan Bom Malam Natal (24/12), ${ }^{9}$ kata "radikalisme" mulai banyak diperbincangkan. Kemudian, dua tahun berikutnya, ledakan bom yang terjadi di Kute, Bali (2002) menandai abad baru "terorisme" dan "radikalisme" di Indonesia. Sejak saat itu, dua kata tersebut menjadi sangat populer di negeri ini. Apalagi, setelah kasus Bom Bali, ledakan bertubi-tubi kembali terjadi, seperti Bom Mega Kuningan (2009), Bom Solo (2011), Teror Bom Buku, serta Bom Thamrin (2016).

Greag Fealy menjelaskan, penggunaan istilah radikalisme Islam tampaknya merupakan kekhasan untuk menyebut fenomena "kebangkitan Islam" di Indonesia. "la merupakan genuine phenomena dari dalam masyarakat Islam di Indonesia". ${ }^{10}$ Sementara Tarmizi Taher mengemukakan bahwa radikalisme 
agama adalah "gerakan dari kelompok Muslimin tertentu yang menolak tatanan yang sudah ada, terutama yang dinilai berasal dari Barat, dan berusaha menerapkan suatu model tatanan tersendiri yang berbasiskan nilai-nilai ajaran Islam fundamental, yaitu al-Qur'an, al-Hadist, dan praktik kehidupan sahabat Nabi generasi pertama." 11

Namun pada dasarnya, radikalisme Islam yang berkembang di Indonesia memiliki banyak "wajah" dan cara. Maksudnya adalah terdapat sebagian kelompok Muslim yang tergabung dalam satu organisasi keagamaan tertentu, yang bercita-cita melakukan repolitisasi politik Islam. ${ }^{12}$ Gelombang politik Islam ini sebagai satu dari sekian wajah radikal Islam yang juga berkembang di dalam negeri. Kelompok ini, sebagaimana acap diketahui, bersuara dengan lantang menginginkan berdirinya Khilafah Islam, dengan menghardik sistem pemerintahan demokrasi yang sudah ada. Sementara kelompok yang berbeda, tetapi mencita-citakan harapan yang sama, ekspresi-ekspresi politiknya ingin menjadikan Islam sebagai dasar negara, namun moral para elitnya tergerus kepentingan politik pragmatis.

Kemunculan berbagai bentuk radikalisme tersebut seiring dengan perkembangan konfigurasi geopolitik dan ekonomi global. Kelompokkelompok radikalis tersebut tumbuh bak jamur di musim hujan dengan memperlihatkan identitasnya sebagai gerakan transnasional yang solid dan sistematis. Keberadaan mereka mewujud dalam bentuk halaqah, usrah, atau daurah di masjid-masjid dan kampus-kampus, serta di kos-kos mahasiswa.

Sebagaimana yang dikemukakan di berbagai media massa, pemerintah Amerika Serikat (AS) mengidentifikasi beberapa organisasi Islam radikalis yang berkembang di Indonesia memiliki keterkaitan dengan ideologi dan jaringan terorisme global (ISIS atau AI-Qaedah), di antaranya adalah: Pertama, Jemaah Islamiyah (J), yang memiliki arti "kelompok Islam" atau "masyarakat Islam". Dalam perspektif intelijen, JI adalah sebuah organisasi keagamaan yang mencita-citakan Darul Islam di kawasan Asia Tenggara. Kelompok ini didirikan oleh Abu Bakar Ba'asyir dan Abdullah Sungkar ketika dalam pelarian di Malaysia. Sejak 2008, pengadilan negeri Jakarta Selatan memutuskan bahwa JI sebagai "korporasi terlarang"13 karena dua tokohnya (Abu Dujana dan Zarkasih) terlibat dalam peristiwa peledakan Bom Bali (2002) yang menewaskan sebanyak 202 orang. Organisasi ini juga dianggap bertanggungjawab pada aksi teror Bom Bali II (2005), Bom Hotel JW Marriot (2003), dan peledakan di depan Kedubes Australia (2004). Sementara itu, pada waktu sebelumnya, pemerintah AS sudah menyebut bahwa Jl adalah organisasi teroris. 
Kedua, Jamaah Ansharot Tauhid (JAT). Organisasi yang berbasiskan keagamaan ini merupakan pecahan dari Majelis Mujahidin Indonesia (MMI) yang didirikan juga oleh Abu Bakar Baasyir di Solo pada 27 Juli 2008. Sebagaimana JI, JAT juga dicap teroris oleh AS dan pemerintahan RI. Sejak awal berdiri, kelompok ini merangkul para anggota teroris yang menjadi buronan dan eks anggota JI. Melalui JAT, Abu Bakar Baasyir mendaklarasikan dukungannya terhadap ISIS yang berada di bawah amir khilafah Abu Bakar Al-Baghdadi. Akan tetapi, langkah Baasyir ini tidak banyak diikuti para anggotanya. Sebagian besar mereka tidak sependapat mengenai dukungan ini karena tidak cocok dengan pergerakan Al-Baghdadi sebagai amir khilafah.

Ketiga, Mujahidin Indonesia Timur (MIT). Kemunculan MIT dilatarbelakangi oleh konflik komunal-keagamaan yang terjadi di Poso, Sulawesi Tengah pada 1998. Gerakan "Laskar Jihad" menggema di kawasan tersebut, sehingga menarik banyak umat Islam dari berbagai daerah untuk terlibat dalam peperangan "Islam-Kristen" tersebut. Setelah konflik ini berakhir, para kombatannya bercokol menjadi kelompok Islam garis keras yang bertanggunggjawab atas sejumlah tindak terorisme di Indonesia. MIT berada di bawah kepemimpinan Santoso, atau Abu Wardah Santoso Asy Syarqy Al Indunisy. Pada Juni 2014, sebuah video diunggah di Youtube berdurasi 12.30 menit, yang isinya mengenai baiat kelompok MIT kepada Daulah Islam atau Khilafah Islamiyyah atau ISIS.

Selain jaringan kelompok teroris yang bercokol di Indonesia pasca Reformasi 1998, beberapa kelompok keagamaan yang dapat dikategorikan sebagai organisasi radikalisme Islam, yaitu: Pertama, Harakah Tarbiyah. "Tarbiyah" memiliki arti pendidikan secara etimologis, namun pada konteks fenomena gerakan keagamaan di Indonesia istilah ini ditujukan untuk menyebut gerakan Islam yang terinspirasi Ikhwanul Muslimin (IM) di Mesir. ${ }^{14}$ IM memiliki dua ideolog terkenal yaitu Hasan al-Banna dan Sayyid Qutb. Meski organisasi keislaman ini sudah berdiri sejak 1927, tetapi doktrin gerakannya tetap membumi hingga hari ini. Ekspansi gerakannya menyebar hingga ke negaranegara lain termasuk di Indonesia.

Model pembinaan di kalangan aktivis Harakah Tarbiyah dapat dikatakan sangat ketat. Gerakannya dibangun dengan rapi dan sistematis mulai pra sekolah hingga masuk perguruan tinggi. Pola pembinaannya dilakukan dengan cara asistensi. Program asistensi bertujuan "merenovasi" pemahaman keagamaan umat Islam. Karena itu, mereka yang mengikuti program asistensi agama Islam berarti menjadi aktivis Tarbiyah. 
Meski secara ideologi Harakah Tarbiyah menolak berbagai pemikiran dan produk yang bersumber dari Barat, namun mereka sangat sadar bahwa untuk mendirikan Negara Islam di Indonesia, juga beberapa negara berpenduduk mayoritas Islam lainnya, perlu berlindung di bawah demokrasi dan mendirikan partai politik yang diakui pemerintah setempat. Pasca tumbangnya era Orde Baru, hal ini dibuktikan para aktivis Tarbiyah dengan membentuk Partai Keadilan, yang saat ini telah berganti nama dengan Partai Keadilan Sejahtera (PKS). ${ }^{15}$ Selain anti demokrasi, Harakah Tarbiyah juga melawan pokok-pokok pikiran modern seperti hak asasi manusia, kesetaraan gender, serta sekulerisme, liberalisme, dan pluralisme.

Kedua, Hizbut Tahrir Indonesia (HTI). Dalam buku yang bertajuk Manifesto Hizbut Tahrir untuk Indonesia disebutkan, HTI merupakan sebuah partai politik yang berideogikan Islam. Organisasi ini berdiri dengan tujuan ingin membebaskan umat manusia dari dominasi, paham, pemikiran, sistem hukum, dan negara kufur menuju paham, pemikiran, sistem hukum, dan negara Islam dengan menerapkan syari'ah Islam secara kaffah dan mengemban dakwah ke seluruh penjuru dunia. ${ }^{16}$ Dengan harapan besar itu, HTI merupakan gerakan politik yang menginginkan supaya Islam menjadi sistem pemerintahan global. Sementara Indonesia, disuarakan untuk menjadi titik awal tegaknya citacita Khilafah Islamiyyah. ${ }^{17}$

Bagi HTI, kepentingan Indonesia menjadi nukleus bagi bangkitnya kekuatan Islam dunia memiliki alasan yang rasional. Secara organisatoris, saat ini HTI telah memiliki struktur kepengurusan yang lengkap mulai dari Dewan Pimpinan Pusat (DPP), Dewan Pimpinan Wilayah (DPW), hingga Dewan Pimpinan Daerah (DPD). Sejak pasca Kongres Internasional pertama Hizbut Tahrir di Gelora Bung Karno (GBK) pada tahun 2000, HTI telah berekspansi ke 31 provinsi dan mempunyai lebih dari 200 distrik di Tanah Air. Terlebih lagi kepengurusan di dalamnya meliputi departemen politik, ekonomi, dan kemahasiswaan. Di lingkungan mahasiswa HTI menjelma menjadi gerakan ekstra kampus Gerakan Pembebasan Mahasiswa (GEMA).

Sistem kepengurusan HTI yang begitu komperhensif tidak dijumpai di negara-negara lain. Apalagi di sejumlah negara di Timur Tengah seperti Mesir, Syiria, Tunisia, Libya, dan Lebanon sangat tidak memungkinkan untuk dijadikan titik awal tegaknya Khila < fah Isla < miyyah. Sejumlah negara berpenduduk mayoritas Islam tersebut tengah mengalami krisis perang saudara yang belum bisa dipastikan kapan akan selesai. Sementara di Indonesia, eksistensi HTI diuntungkan dengan keterbukaan sistem demokrasi yang mengakomodasi 
semua organisasi. Sehingga gerakan HTI pun tumbuh dan berkembang secara cepat.

Upaya radikal HTI yang ingin mendirikan Daulah Islam dipandang sebagian besar umat Islam sebagai cita-cita yang ilutif. ${ }^{18}$ Bahkan langkah Hizbut Tahirir/ HTI sebagai partai politik juga dinilai sebagai sikap yang "munafik", karena tidak mampu memainkan fungsi-fungsi kepartaian sebagaimana yang dipraktikkan partai-partai politik modern saat ini. Haedar Nashir melakukan kritik tegas terhadap HTI dengan mengatakan bahwa gerakan ini bukan merupakan partai politik Islam, melainkan sekedar organisasi kemasyarakatan biasa yang bergerak di bidang pendidikan agama dan sosial. Jika mereka benar partai politik mestinya masuk dalam sistem demokrasi di Indonesia. Namun, sepertinya HTI memiliki pengertian sendiri tentang partai politik dan demokrasi. ${ }^{19}$

Strategi perjuangan Islam HTI sebagai partai politik dengan pengertiannya sendiri dikategorikan Kasinyo Harto dengan sebutan fundamentalisme Islam radikal. ${ }^{20}$ Pasalnya, di dalam sebuah Negara Kesatuan Republik Indonesia (NKRI) HTI menantang demokrasi dan melawan pokok-pokok pikiran negara modern seperti nasionalisme, patriotisme, dan cinta Tanah Air. Kasinyo menjelaskan, keinginan mereka untuk mendirikan negara Islam terlampau kuat. Mereka dapat melakukan apa saja hingga titik darah penghabisan pun akan dilakukan demi merebut cita-cita yang diimpikan.

Latar belakang berdirinya Hizbut Tahrir sebagai sebuah partai politik Islam didasarkan pada perintah Allah SWT. ${ }^{21}$ Organisasi keagamaan transnasional tersebut mempercayai bahwa kelahiran Nabi Muhammad dengan membawa ajaran Islam adalah untuk mengatur seluruh aspek hidup manusia dan menyelesaikan berbagai permasalahan yang mereka hadapi. Dan, satu-satunya jalan untuk mengatur segala aspek kehidupan itu adalah dengan berdirinya sebuah Daulah Islam. Umat Islam di seluruh dunia harus bersatu dan berlindung dalam satu pemerintahan Khilafah. Dengan begitu kehidupan yang sesuai dengan norma-norma keislaman akan terwujud.

Ketiga, Jamaah Salafi. Kelompok ini memimpikan kehidupan masyarakat Islam sebagaimana pada zaman Nabi Muhammad saw dan para salaf alsaleh. Sejatinya, kehadiran Jamaah Salafi di Indonesia telah ada sejak sekitar 1980-an. Sayangnya, ekspansi gerakannya tidak terlalu mencolok, ditambah jumlah kadernya tidak pernah mengalami peningkatan secara signifikan. Fokus perhatian gerakan ini lebih menempatkan diri sebagai kelompok belajar Islam daripada menyuarakan politik Islam. 
Mereka sedikit pun tidak ingin terlibat dalam percaturan politik atau menyoal persoalan kebangsaan. Mereka hanya cukup menginginkan kelompok belajar agar umat Islam memahami dengan betul doktrin-doktrin keislaman sebagaimana yang dipahami oleh Nabi Muhammad saw dan para sahabatsahabatnya.

Dalam berbagai kajiannya, Jamaah Salafi menggunakan sejumlah kitab Islam klasik seperti buku karangan Muhammad bin Abdul Wahab di antaranya Usuulu al-Thalathah, Sharah Kitab al-Tauhid, dan Kashfu al-Subhaat, buku karya Ibnu Taimiyah al-Aqidah al-Washithiyah, serta buku karya Abdul Halim Uwais Mushkilaatul al-Shabaab fii Dlau'il Islaam. Berbagai kitab tersebut mengajarkan tentang Tauhid, Aqidah, dan prilaku kesalehan. Buku Usuulu alThalaathah misalnya, tulisan Abdul Wahab pendiri gerakan Wahabi di Arab Saudi ini tidak lain mengajarkan ilmu Tauhid, yang sumbernya berasal dari ayat-ayat Al-Qur'an. Penyebutan Usuulu al-Thalaathah sendiri didasarkan pada pertanyaan-pertanyaan siapa tuhanmu (man rabbuka), siapa nabimu (man nabiyyuka), dan apa agamamu (maa diinuka).

Secara eksplisit, kemunculan mereka ingin menampilkan varian gerakan Islam yang kaku (rigid) dibanding kelompok muslim lainnya di Indonesia. Performa fisik yang berbeda itu menempatkan Jamaah Salafi sebagai gerakan yang suka menyendiri (alienation). Tidak salah jika Noorhaidi Hasan menyebut mereka sebagai gerakan Islam yang bercorak "kesunyian apolitis". ${ }^{22}$ Pasalnya, selain mereka memperkenalkan model keislaman yang kaku, Jamaah Salafi juga menghindari permasalahan-permasalahan politik praktis. Seperti diketahui, selama ini kelompok Salafi lebih dikenal sebagai gerakan yang hanya fokus memberikan pemahaman keagamaan baik di lingkungan masyarakat secara umum, maupun di lingkup mahasiswa. Mereka beralasan karena perbuatan ini sesuai dengan yang diteladakan para salafus al-shalih.

Sementara Kasinyo Harto menyebut kelompok Jamaah Salafi sebagai gerakan Islam fundamentalis-literalis. Pendapat ini kiranya tidak berlebihan karena didasarkan pada corak pemikiran, model pembelajaran, dan cara pandang mereka yang menginginkan kembalinya kehidupan umat Islam seperti pada masa salafus al-saalih. Dalam perspektif aktivis salafi, meski masyarakat kini dihadapkan pada era kontemporer yang sarat dengan kemajuan teknologi dan liberalisasi pemikiran, namun senyatanya bisa dibawa kembali pada masa salaafus al-shalih. ${ }^{23}$ Karena itu, diperlukan pemurnian (purifikasi) pemikiran Islam sebab umat Islam kini semakin menyimpang dari sumber agama yang otentik yaitu al-Qur'an dan al-Hadist. 
Perspektif keagamaan yang mengarusutamakan pandangan Jamaah Salafi kepada salaafus al-saalih merupakan "pemaksaan" total. Para aktivisnya mengkhayalkan sebuah kehidupan yang didominasi dengan terma Islam ala salaafus al-shalih, di mana generasi terbaik umat ada seperti para sahabat, tabi'in dan tabi'ut tabi'iin. Gerakan romantisme Islam diwujudkan dengan membuat kelompok-kelompok kecil diskusi di masjid. Mereka menilai bahwa tradisi yang bersemi pada zaman salaafus al-shalih semuanya dipukul rata sebagai "yang terbaik dan yang paling benar", sementara tradisi yang muncul belakangan (zaman modern) dianggap keburukan. Akibatnya, pemahaman para aktivis salafi cenderung monolitik dalam melihat permasalahan. Mereka menilai setiap problem harus dikembalikan pada tata aturan yang diteladankan umat salaf, tidak terkecuali problem yang muncul di era kontemporer sekalipun.

\section{Keriuhan di Media Sosial}

ISIS, organisasi teroris yang paling banyak dibicarakan di era kekinian, ketika mendeklarasikan diri dapat dikatakan unik karena tidak dengan iringiringan alutsista militer, konferensi pers, atau pengumuman dengan melakukan penahanan warga sipil. Akan tetapi, kelompok radikal yang dikomandani oleh Abu Bakar Al-Baghdadi ini mengumumkan pendiriannya melalui media sosial. Pada 2013, ISIS pertama kali melakukan kicauan menggunakan akun @e3tasimo dengan nama akun /'tisamm²4 untuk menunjukkan keberadannya.

Sejak itu, ISIS terus melakukan propaganda dan menebar ancaman ke sejumlah negara melalui video-video yang diunggah ke YouTube. Salah satu fakta yang paling mengerikan yaitu ketika ISIS mengeksekusi reporter asal AS dengan memenggal kepalanya. Kemudian, video pemenggalan tersebut disebar melalui media sosial. Pada kasus lain, sebelum penembakan yang menewaskan 14 orang di San Bernardino, California oleh Syed Rizwan Farook dan Tashfeen Malik pada 2 Desember 2015 terjadi, pasangan suami-istri tersebut menulis di akun Facebook-nya masing-masing dengan mengungkapkan kesetiaannya terhadap ISIS. Sejumlah fakta tersebut menjelaskan kepada masyarakat global bahwa sesungguhnya media sosial bukanlah semata-mata dimanfaatkan kelompok teroris untuk menebar teror, melainkan membuktikan kecanggihan dan identitas mereka sebagai bagian yang tidak buta teknologi.

Pemanfaatan jaringan virtual, khususnya media sosial oleh ISIS, adalah fenomena global yang tentu saja berkait kelindan dengan maraknya aksi terorisme di Indonesia. Jaringan teroris di Tanah Air juga tidak dapat dilepaskan dengan pemanfaatan jejaring sosial untuk melancarkan strategi dan agenda 
mereka. Apalagi pengguna internet di Indonesia mengalami peningkatan yang pesat setiap tahunnya. Laporan penelitian yang dikeluarkan Asosiasi Penyelenggara Jasa Internet Indonesia (APJII) bersama Pusat Kajian Komunikasi (Pusakom) Universitas Indonesia 2014 menjelaskan, pertumbuhan jumlah pengguna internet di dalam negeri terus meningkat sejak 2005. Pada tahun itu, jumlah pengguna dunia maya mencapai sebanyak 16 juta orang, namun meningkat drastis menjadi 88,1 juta netizen (34,9\% dari jumlah penduduk Indonesia 252,4 juta jiwa) pada 2014.25

Beberapa peristiwa yang bisa diambil contoh ialah, bahwa dua bulan sebelum serangan teror bom di Jalan Thamrin, Jakarta Pusat terjadi, muncul sebuah akun Facebook yang mengunggah rekaman audio yang diduga milik Santoso, pemimpin Mujahidin Indonesia Timur (MIT), jaringan teroris yang beroperasi di Poso, Sulawesi Tengah. Meski rekaman berjudul "Seruan Sang Komandan" tersebut hanya berdurasi 9 menit, namun propaganda itu bermaksud menghancurkan Markas Kepolisian Daerah Metro Jaya dan Istana Merdeka, Jakarta.

Selain itu, yang tidak kalah menghebohkan, kemunculan video anak-anak Indonesia yang tengah dilatih perang oleh ISIS yang tersebar di YouTube pada Maret 2014. Serta kasus lain, ketika kelompok Rizky Gunawan berhasil mengumpulkan dana sebesar Rp5 milyar dari hasil meretas sejumlah situs komersil untuk membiayai pelatihan militer teroris di Poso. ${ }^{26}$

Kasus-kasus ini menjelaskan bahwa dunia maya telah menjadi kekuatan nyata yang menghubungkan soliditas dan militansi kelompok radikal hingga ke lintas negara. Keberadaannya menawarkan kemudahan dalam berinteraksi, mengorganisasi, melakukan perekrutan, propaganda, dan mencari pendanaan. Tidak mengherankan bila keberadaan jejaring sosial turut merubah strategi dan pola teror yang lebih masif dan sistematis. Bahkan, pada dekade kedua abad ke-21 ini, muncul kecenderungan kelompok radikal meningkatkan interaksi dan propagandanya di dunia virtual. Mereka membuat laman-laman tertentu untuk menyebarkan ide dan gagasan kebencian, pemahaman radikal, ancaman, serta cara membuat bom secara otodidak. Sejumlah website tersebut disembunyikan identitasnya dengan alat teknologi enkripsi yang belum diketahui. Pada akhir 2014, misalnya, Twitter menemukan fakta yang mengejutkan bahwa ISIS telah membuat 700.000 akun Twitter yang punya koneksi dengan berbagai kelompok teroris di belahan dunia. Hal ini membuat manajemen perusahaan berlogo burung biru itu mengawasi secara ketat konten-konten yang dicurigai berisikan agenda terorisme. 
Seiring dengan kontrol yang begitu ketat, kelompok radikal tetap tidak kehilangan akal dan terus berkicau menggunakan akun-akun beranonim. Penggunaan meme-meme bergambar yang berisikan pesan radikal juga mereka buat dalam rangka menarik simpati anak-anak muda. Kemudian, secara konsisten dan kreatif, berbagai gambar meme itu disebar ke Facebook, Twitter, Instagram, dan WhatsApp yang menjangkau ribuan netizen dalam waktu singkat.

Kaitannya dengan hal ini, United Nations Office on Drugs and Crime (UNODC) pada 2011 telah mengidentifikasi tujuh bentuk penggunaan dunia maya untuk kepentingan kelompok radikal, diantaranya: Propaganda, perekrutan, pendanaan, pelatihan, perencanaan, penyebaran teror, dan cyberattack. Dalam banyak kasus, strategi cyberspace ini telah dipraktikkan oleh semua jaringan kelompok teroris, baik di tingkat global (Al-Qaedah dan ISIS) maupun lokal (Jemaah Islamiyah dan Jamaah Ansharut Tauhid).

Pemanfaatan media sosial menjadi cara baru bagi kelompok radikal Islam untuk menyebarkan benih-benih ekstrimisme. Facebook, YouTube, Twitter, blog hingga aplikasi layanan pesan gratis seperti WhatsApp sekarang merupakan alat yang ampuh bagi kelompok teroris dan Islam transnasional untuk melakukan propaganda, mendapatkan pengaruh, dan menjaring keanggotan warga di jejaring sosial. Pola perubahan strategi gerakan yang lebih canggih ini bukan hanya dilakukan oleh kelompok teroris, seperti ISIS, JI, dan JAT, melainkan juga berbagai organisasi Islam transnasional, misalnya $\mathrm{HTI}$, Jamaah Salafi, dan Harakah Tarbiyah. ${ }^{27}$ Ada banyak akun di jejaring sosial dan blog yang dikelola HTI, Salafi, dan Tarbiyah yang isinya mengajak mendirikan Khilafah Islamiyyah, menerapkan politik Islam, menyingkirkan demokrasi sebagai sistem pemerintahan nasional, serta menolak produk, ide, dan pemikiran yang bersumber dari Barat seperti HAM, kesetaraan gender, pluralisme, sekulerisme, dan liberalisme. Jalan propagandanya dilakukan dalam bentuk pembuatan video kegiatan, kicauan berkala, dan pokok-pokok keputusan internal organisasi. Akun-akun tersebut berjalan secara sistematis dan disebarkan dengan sangat luas, hingga ke lingkungan perguruan tinggi. ${ }^{28}$

\section{Situs dan Akun Media Sosial Radikal}

Terdapat banyak laman, portal online, dan akun media sosial yang diindikasi memuat konten-konten berpaham pemikiran radikal. Laman yang memiliki kecenderungan dikelola dan dimiliki para aktivis Harakah Tarbiyah yaitu, www.pkspiyungan.org. Mulai awal Januari 2016, portal tersebut berganti 
domain menjadi www.portalpiyungan.com. Laman ini berdiri pertama kali pada 2008. Mulanya, portal ini hanya berbentuk blog dengan alamat urlpkspiyungan.blogspot.com dan menjadi media komunikasi Dewan Pengurus Cabang (DPC) PKS di kecamatan Piyungan Yogyakarta.

Gaya pemberitaan yang provokatif dan propagandis membuat situs online ini menjadi rujukan para anggota PKS. Bahkan, dikatakan bahwa kepopulerannya mengalahkan situs resmi PKS pusat www.pks.or.id pada waktu itu. ${ }^{29}$ Portalpiyungan. com memosisikan diri sebagai representasi dari media yang memperjuangan umat Islam. Tema dan fokus pemberitaannya diamati hampir semuanya dengan perspektif keagamaan. Akan tetapi, pilihan judul dan angle penulisan diambil dengan pilihan negasi bernada propaganda. Dalam menyoroti majunya Basuki Tjahaja Purnama (biasa dikenal Ahok), misalnya, laman ini berada di posisi melawan dengan membenturkan Ahok dengan umat Islam. Artikel dan foto pemberitaan tentang Ahok dapat dipastikan bernada memojokkan dan terksan anti Islam. Hal ini karena Ahok bukanlah dari kalangan Islam, bahkan ia disebut sebagai pemimpin kafir dan lalim. Terlebih sejumlah kebijakannya dianggap memprioritaskan kepentingan pemodal (bukan Muslim) yang merugikan umat Islam. ${ }^{30}$

Contoh yang lain, seperti pada kasus aksi terorisme yang terjadi di Jalan Thamrin Jakarta Pusat, awal tahun 2016. Meski portal ini tidak sepakat dengan tindakan terorisme yang terjadi di Indonesia maupun di negara-negara lain, yang hal itu bisa diamati dari sejumlah pemberitaannya, namun kemunculan peristiwa peledakan bom teror dalam analisisnya dipandang sebagai pengalihan isu belaka. Artikel berita tentang teror bom di Sarinah dianggap pengalihan isu atas kesepakatan pemerintah dengan Freeport. ${ }^{31}$

Tidak cukup dengan portal online, sebagaimana yang dipraktikkan mediamedia mainstream di Indonesia, portalpiyungan.com memposting dan membagikan berita-beritanya melalui media sosial. Akun Facebook resmi yang dimilikinya bernama "portalpiyungan", dengan 77.864 pengunjung yang menyukai akun tersebut sejak dibuat awal tahun 2016.32 Setiap satu artikel bernada provokatif yang diunggah ke Facebook dibagikan dan disebar ke media sosial lain seperti WattsApp atau BBM, kisarannya ada yang mencapai di atas 50 kali shares, di atas 100 shares, bahkan lebih dari 1.000 shares. Hebatnya lagi, setiap artikel yang diunggah hampir selalu mendapat komentar dari pengunjungnya dalam jumlah yang besar dan bernada membela. Sementara akun Twitter-nya dengan nama@portalpiyungan memiliki sebanyak 1,706 pengikut dengan 1,675 kicauan sejak dibuat awal tahun 2016. 
Sedangkan yang terjadi pada HTI, dalam menyuarakan aspirasinya, gerakan ini melakukan berbagai cara seperti demonstrasi, mengadakan seminar keislaman, serta aksi publikasi. Untuk strategi publikasi HTI menerbitkan buku, ${ }^{33}$ majalah Al-Wa'ie, bulletin Al-Islam, dan tabloid Media Umat. ${ }^{34}$ Materi-materi rubrikasi berisi cemoohan terhadap demokrasi, NKRI, dan Pancasila. Sementara konsep Khilafah Islamiyyah ditampilkan sebagai solusi setiap permasalahan.

Selain menggunakan strategi publikasi lewat penerbitan buku, tabloid, majalah, dan buletin, HTI juga gencar mendakwahkan perjuangannya melalui media sosial. Akun Facebook DPP HTI, misalnya, dengan alamat "Hizbut Tahrir Indonesia", fanpage ini telah mendapatkan tanda Like dari 58.267 orang. ${ }^{35}$ Jika dibanding dengan jumlah mayoritas penduduk umat Islam di Indonesia, angka relatif kecil mengingat akun ini sudah dibuat sejak 2010. Sementara akunTwitter-nya, @HizbuttahrirlD diikuti oleh 37,2 ribu (37.2 K) pengikut dan telah melakukan 26,5 ribu (26.5 K) kicauan. Selain aktif bersuara di Facebook dan Twitter, HTI juga bergerak di Instagram, Google+, dan blogblog. Laman resmi DPP HTI yaitu hizbut-tahrir.or.id.

Aktivitas HTI melalui media sosial sangat terorganisir secara baik. Terbukti, akun Facebook DPP HTI tersebut membagi postingan-postingan berita, keputusan organisasi, agenda kegiatan, serta pemikirannya setiap hari, baik berbentuk artikel berita, foto-foto, meme-meme bergambar, maupun video pendek. Strategi ini juga diikuti oleh puluhan akun Facebook dan Twitter HTI dan sayap organisasinya (Muslimah HTI dan Gema Pembebasan) di tingkat daerah dan propinsi. Akun-akun ini juga aktif menanggapi berbagai persoalan kebangsaan, khususnya moral anggota legislatif, mengecam keborokan pemerintah, dan memberikan solusi setiap permasalahan dengan mendirikan Daulah Islam. Kedua akun media sosial HTI tersebut dikendalikan secara berkelanjutan oleh bidang Infokom DPP HTI.

HTI juga memanfaatkan fungsi YouTube. Kelompok ini senantiasa mengunggah rekaman video berbagai kegiatan penting melalui jejaring sosial berbentuk video tersebut. Acara Muktamar Khilafah atau Kongres Internasional HTI, misalnya, rekaman video keduanya mudah ditemukan di YouTube. Bahkan, di antara beberapa unggahannya itu dikunjungi oleh ribuan orang. Berbagai rekaman yang mereka unggah juga diikuti dengan komentar/tanggapan, pujian, dan dukungan dari banyak aktivisnya di berbagai negara. Sementara sekali waktu, video itu terkadang juga mendapat kritik yang mempertanyakan eksistensi HTI sebagai partai politik yang mengatasnamakan Islam. Meski begitu dukungan terhadap organisasi bentukan syekh Taqyuddin An-Nabhani ini tetap 
kuat.

Dakwah HTI melalui pemanfaatan media sosial dapat dipandang sebagai satu dari sekian strategi modern yang mereka miliki. Seperti LSM atau ormas Islam pada umumnya, HTI di era pasca Orde Baru telah mampu menciptakan opini publik dan berhasil memobilisasi aktivisnya dalam jumlah yang besar. Mereka dimobilisasi untuk melakukan aksi demonstrasi atau sekedar bersuara di media sosial. Cepatnya pemikiran dan gagasan HTI yang diadopsi para aktivisnya tidak lain dikarenakan militansi dan loyalitas mereka yang terbilang solid. Bahkan, jika ada yang tidak setuju (terutama orang di luar HTI) terhadap ide yang didakwahkan, maka secara cepat mereka akan dibilang kafir atau kata-kata kasar lainnya.

Sementara itu, meski Salafi dan kelompok Islam fundamentalis lainnya, mengklaim anti modernitas dan produk-produk Barat, namun jamaah ini tidak tertinggal dalam pemanfaatan media sosial sebagai tempat dakwah mereka di dunia maya. Terdapat beberapa akun Facebook dan Twitter yang terindikasi berpaham Salafi. Namun akun-akun tersebut dikelola secara individu dan tidak sistematis. Sebagai contoh adalah akun Facebook "Dakwah Salafiyah Ahlus Sunnah Wal Jama'ah" yang dikelolah oleh seorang aktivis Salafi bernama Damar Yustian. Menurut Damar, dikutip dari salah satu postingannya, akun ini berdiri sejak 31 Juli 2015 untuk menggantikan grup akun ("Tegar di Atas Sunnah") yang sebelumnya diretas oleh pihak tidak bertanggungjawab. Diamati dari konten dan konsistensi pemberitaannya, grup ini tidak dikelola secara baik. Hal ini mengesankan bahwa memang Salafi bukanlah organisasi yang memiliki struktur kepengurusan seperti halnya HTI atau Tarbiyah di kampuskampus atau partai politik.

\section{Simpulan}

Strategi berbagai kelompok radikal yang menjadikan media sosial sebagai basis propaganda dan perekrutan anggota baru sangatlah mengancam masa depan kebangsaan. Apalagi, seperti dijelaskan sebelumnya, target utama mereka adalah kalangan anak muda yang jumlahnya mencapai lebih dari separuh dari total penduduk di Indonesia. Infiltrasi nilai-nilai kekerasan, kebencian, dan permusuhan dengan mendasarkan pada dalil-dalil keagamaan akan mudah diikuti para generasi muda, terlebih mereka tengah berada pada usia pencarian jati diri.

Para aktivis radikal Islam tidak menerima paham-paham kebangsaan, seperti nasionalisme, cinta tanah air, patriotisme, dan demokrasi. Dengan begitu, 
ideologi kelompok fundamentalis ini bukan hanya berpotensi mencabik ketentraman masyarakat beragama, melainkan juga membahayakan pada semua "keintiman" sektor nasional: pertahanan dan keamanan, stabilitas ekonomi-politik, dan peradaban bangsa.

Melihat kenyataan tersebut, dalam KTT AS-Asean di California, AS, pada Februari 2016, Presiden Joko Widodo berpidato mengenai pentingnya memanfaatkan media sosial untuk membendung gerakan ekstrimis terorisme. Di hadapan para pemimpin negara se-Asia dan AS, Jokowi mengajak warga dunia untuk melawan paham-paham radikal yang menyusup di keramaian dunia maya. Tidak cukup bila penanggulangan terorisme dan ideologi-ideologi radikalisme Islam hanya dilakukan lewat program sosialisasi deradikasilasi agama "di bawah ruang ber-AC". Program ini hanya akan menghabiskan anggaran negara, sedangkan secara substansi tidak mampu menyelesaikan dan menghapus cara pandang sebagian orang yang mulai berpikiran menyimpang dan menebar ujaran kebencian.

Dalam hal ini, salah satu upaya yang bisa dilakukan untuk mengatasi masalah atau paling tidak meminimalisir terjadinya radikalisasi di ruang maya, pemerintah bersama komunitas digital hendaknya perlu menyikapi keberadaan grup-grup percakapan di media sosial yang mengarah kepada radikalisme secara serius. Caranya adalah menyerang balik dengan membuat grup-grup percakapan yang berorientasi pada deradikalisasi agama sekaligus menutup akun-akun kelompok fundamentalis yang dinilai membenihkan ideologi radikal.

\section{Catatan Akhir}

1 Untuk pembahasan yang lebih lengkap tentang Perda Syari'ah, baca dalam Haedar Nashir, Islam Syariat; Reproduksi Salafiyah Ideologis di Indonesia (Jakarta: Mizan dan Maarif Institute, 2013), 292-379. Baca juga dalam Wasisto Raharjo Jati, "Permasalahan Implementasi Perda Syariah dalam Otonomi Daerah", al Manahij, Vol. vii No.2 Juli 2013, 305-315

2 Penelitian yang dilakukan oleh Center for the Study of Religion and Culture (CSRC) UIN Syarif Hidayatullah Jakarta pada tahun 2008-2009 menjelaskan tentang fenomena sebagian masjid di Jakarta dan Solo yang menjadi benih bagi tumbuhnya gerakan radikalisme Islam di Indonesia. Selengkapnya baca dalam laporan risetnya, Ridwan al-Makassary dan Ahmad Gaus AF, ed., Benih-benih Islam Radikal di Masjid: Studi Kasus Jakarta dan Solo (Jakarta: CSRC UIN Jakarta, 2010).

3 Baca selengkapnya dalam Khamami Zada, "Wajah Radikal Penerbitan Islam di Indonesia”, Indo-Islamika, Vol 1, No. 1, 2011/1432, 1-19.

4 Keanggotaan Harakah Tarbiyah tumbuh dengan sangat pesat pasca Orde Baru 
lengser. Hal ini tidak lain dipengaruhi oleh geliat para aktivisnya yang berada di lingkungan kampus. Bahkan, organisasi Tarbiyah yang menjelma menjadi Lembaga Dakwah Kampus (LDK) di sejumlah kampus negeri di Indonesia menggagas sebuah partai politik, yaitu Partai Keadilan, kini berganti nama menjadi Partai Keadilan Sejahtera (PKS). Baca dalam Ali Said Damanik, Fenomena Partai Keadilan; Transformasi 20 Tahun Gerakan Tarbiyah di Indonesia (Jakarta: Teraju, 2002), 218-261. Lihat juga dalam Nafi’ Muthohirin, Fundamentalisme Islam; Gerakan dan Tipologi Pemikiran Aktivis Dakwah Kampus (Jakarta: IndoStrategi, 2014), 137-145

5 Sebelum era Reformasi, tercatat hanya ada dua peristiwa terorisme yang terjadi di Indonesia, yaitu: Pertama, aksi terorisme yang terjadi pada 1981. Sebuah penerbangan maskapai Garuda Indonesia dari Palembang ke Medan pada penerbangan dengan pesawat DC-9 Woyla yang berangkat dari Jakarta pada pukul 08:00 wib, transit di Palembang, dan akan terbang ke Medan dengan perkiraan sampai pada pukul 10.55 wib. Dalam penerbangan, pesawat tersebut dibajak oleh 5 orang teroris yang menyamar sebagai penumpang. Mereka bersenjata senapan mesin dan granat, dan mengaku sebagai anggota Komando Jihad; 1 kru pesawat tewas; 1 tentara komando tewas; 3 teroris tewas. Kedua, Bom Candi Borobudur 1985, 21 Januari 1985. Peristiwa terorisme ini adalah peristiwa terorisme bermotif "jihad" kedua yang menimpa Indonesia.

6 Bom meledak dari sebuah mobil yang di parkir di depan rumah Duta Besar Filipina, Menteng, Jakarta Pusat, pada 01 Agustus 2000. Tercatat 2 orang tewas dan 21 orang lainnya luka-luka, termasuk Duta Besar Filipina Leonides T Caday.

7 Bom Kedubes Malaysia, 27 Agustus 2000. Granat meledak di kompleks Kedutaan Besar Malaysia di Kuningan, Jakarta. Tidak ada korban jiwa.

8 Bom Bursa Efek Jakarta, 13 September 2000. Ledakan mengguncang lantai parkir P2 Gedung Bursa Efek Jakarta. Tercatat sebanyak 10 orang tewas, 90 orang lainnya luka-luka. Sebanyak 104 mobil rusak berat, 57 rusak ringan.

9 Bom malam Natal, 24 Desember 2000. Serangkaian ledakan bom pada malam Natal di beberapa kota di Indonesia, merenggut nyawa 16 jiwa dan melukai 96 lainnya serta mengakibatkan 37 mobil rusak.

10 Greag Fealy, "Inside the Laskar Jihad: An Interview with the Leader of A New Radical and Militant Sect,” Inside Indonesia, January-March 2001: http: // www.insideindonesia.org/dit 71/fealy. Dikutip dari Ali Muzakir, "Kelompok Islam Radikal di Indonesia: Prospek dan Solusinya," dalam Bahtiar Effendy dan Soetrisno Hadi (ed), Agama dan Radikalisme di Indonesia (Jakarta: Nuqtah, 2007), 227-228

11 Lihat dalam Tarmizi Taher, "Anatomi Radikalisme Keagamaan dalam Sejarah Islam," dalam Bahtiar Effendy dan Handro Prasetyo (penyt.), Radikalisme Agama (Jakarta: PPIM-IAIN, 1998), 8. Definisi kelompok radikal Islam yang dikemukakan Tarmizi Taher ini diamini oleh Khamami Zada dalam membuat kategorisasi kelompok-kelompok radikalisme Islam. Untuk lebih lengkapnya baca dalam Khamami Zada, Islam Radikal: Pergulatan Ormas-ormas Islam Garis Keras (Jakarta: Teraju, 2002), 8 
12 Untuk mengetahui mengenai tumbuhnya kelompok fundamentalisme Islam sebagai akibat dari tantangan geopolitik dan ekonomi global, baca dalam Bassam Tibi, The Challange of Fundamentalism: Political Islam the New World Disorder (London: University of California Press, 1998). Lihat juga, Noorhaidi Hasan, "Ideologi, Identitas dan politik Kekerasan: Mencari Model Solusi Mengatasi Ancaman Radikalisme dan Terorisme di Indonesia," Prisma, Vol. 29. LP3ES, Oktober (2010), 3-24

13 Lihat dalam, http://www.theage.com.au/news/national/jemaah-islamiah-declared-forbidden/2008/04/21/1208742852708.html. Dikutip pada Jum'at (11 Maret 2016).

14 Untuk mengetahui lebih lengkap pola gerakan Islam politik Ikhwanul Muslimin baca dalam Olivier Roy, The Failure of Political Islam (London: I.B. Tauris \& Co Ltd, 1994), 75-89.

15 Selengkapnya baca dalam, Ali Said Damanik, Fenomena Partai Keadilan; Transformasi 20 Tahun Gerakan Tarbiyah di Indonesia (Jakarta: Teraju, 2002).

16 Lihat, Manifesto Hizbut Tahrir untuk Indonesia: Indonesia, Khilafah dan Penyatuan Kembali Dunia Islam (tanpa penulis, HTI: 2009), 67

17 Wawancara aktivis HTI Universitas Indonesia, Arman Surya Hadi, pada 25 Maret 2013.

18 Baca dalam Abdurrahman Wahid (ed.). Ilusi Negara Islam: Ekspansi Gerakan Islam Transnasional di Indonesia (Jakarta: LibForAll Foundation, 2009), 39. Disebutkan, bahwa para agen gerakan Islam transnasional tersebut datang ke Indonesia membawa petrodollar dalam jumlah yang fantastis untuk melakukan Wahabisasi, merusak Islam Indonesia yang spiritual, toleran, dan santun, dan mengubah Indonesia sesuai dengan ilusi mereka tentang negara Islam yang di Timur Tengah pun tidak ada.

19 Baca dalam Haedar Nashir, Islam Syariat: Reproduksi Salafiyah Ideologis di Indonesia (Bandung:, Mizan, 2013), 403-404

20 Lihat dalam Kasinyo Harto. Islam Fundamentalis di Perguruan Tinggi Umum: Kasus Gerakan Keagamaan Mahasiswa Universitas Sriwijaya Palembang (Jakarta: Badan Litbang dan Diklat Departemen Agama RI, 2008), 167.

21 Didasarkan pada Qs. Ali-Imran (3): 104, yang berbunyi: "Dan hendaklah ada di antara kamu segolongan umat yang menyeru kepada kebajikan, menyuruh kepada yang ma'ruf dan mencegah dari yang munkar; Merekalah orang-orang yang beruntung."

22 Baca Noorhaidi Hasan, "Ideologi, Identitas dan Ekonomi Politik Kekerasan: Mencari Model Solusi Mengatasi Ancaman Radikalisme dan Terorisme di Indonesia”, Prisma, Vol. 29 (2010), 7-8

23 Wawancara aktivis Salafi, ustadz Sulhan Jauhari Lc, pada Kamis, (19/9/2013).

24 I'tisamm berasal dari kata Bahasa Arab, yang memiliki arti mempertahankan tradisi Islam tanpa penyimpangan. Baca selengkapnya dalam Kompas, "Predator Nyata di Dunia Maya”, Kompas (Kamis, 17 Desember 2015).

25 Dilihat dari usia netizen, riset tersebut menjelaskan, sebanyak 49\% atau hampir setengahnya berusia 18 tahun hingga 25 tahun. Sementara, jenjang pendidikan mereka $64,7 \%$ lulusan SMA sederajat. Sebanyak $87 \%$, para netizen ini mengaku 
menggunakan media sosial saat terkoneksi dengan internet, sedangkan 68,7\% untuk searching dan browsing.

26 Baca selengkapnya dalam Petrus Reinhard Golose, Invasi Terorisme ke Cyberspace (Jakarta: Yayasan Pengembangan Ilmu Kepolisian/YPKIK, 2015), v-vi

27 HTI, Jamaah Salafi, dan Tarbiyah masuk dalam kategori sebagai gerakan radikal Islam sebagaimana definisi yang dikemukakan oleh Khamami Zada. Dia menjelaskan bahwa kategori yang melekat pada kelompok Islam radikal di Indonesia dapat didasarkan pada empat hal. Pertama, mereka memperjuangkan Islam secara totalistik (kaffah); syariat Islam sebagai hukum negara, Islam sebagai dasar negara, sekaligus Islam sebagai sistem politik sehingga bukan demokrasi yang menjadi sistem politik nasional. Kedua, mereka mendasarkan praktik keagamaannya pada orientasi masa lalu (Salafi). Ketiga, mereka sangat memusuhi Barat dengan segala produk peradabannya, seperti sekulerisasi dan modernisasi. Keempat, perlawanannya dengan gerakan liberalisme Islam yang tengah berkembang di kalangan Muslim. Dikutip dari Khamami Zada, Islam Radikal: Pergulatan Ormas-ormas Islam Garis Keras (Jakarta: Teraju, 2002), 18.

28 Untuk menggali lebih dalam tentang aktivisme kelompok radikalisme Islam di lingkungan kampus, baca dalam Nafi' Muthohirin, Fundamentalisme Islam; Gerakan dan Tipologi Pemikiran Aktivis Dakwah Kampus (Jakarta: IndoStrategi, 2014)

29 Lihat, http://islamedia.id/situs-pkspiyungan-org-ganti-domain/. Dikutip pada Sabtu, 12 Maret 2016, pukul 14:45

30 Beberapa judul berita yang memojokkan Ahok sebagai anti-Islam, di antaranya: "Korban Ahok semua Muslimah Berjilbab, Apa Kebetulan Semata", "Panik, Tim Kampanye Ahok 'Jualan Agama' Mengaku Muslim untuk Cari Dukungan”, Sungguh Keji! Ahokers Halalkan Segala Cara", dan "Sementara Teman Ahok Bergerak di Mall-Mall, Relawan Muslim ACT Bergerak Bantu Korban Banjir,”. Lihat dalam, http://www.portalpiyungan.com. Dikutip pada Sabtu, 12 Maret 2016, pukul 15:07

31 Lihat, http://www.portalpiyungan.com/2016/01/bertepatan-deadline-freeportbom.html. Dikutip pada Sabtu, 12 Maret 2016, pukul 15:20

32 Terakhir dikutip pada Sabtu, 12 Maret 2016, pukul 15:39

33 Sebagian besar buku HTI diterbitkan oleh penerbit HTI sendiri, Pustaka Thariqul Izzah, di Bogor. Dikutip dari Burhanuddin Muhtadi, "The Quest for Hizbut Tahrir in Indonesia”, The Asian Journal of Social Science, (NUS \& Brill) 37 (2009), 628

34 Agensi tabloid Media Umat berjumlah ratusan agen, yang tersebar di kota-kota besar di Indonesia seperti di Jakarta, Jawa Barat, Banten, Jawa Timur, Jawa Tengah, Yogyakarta, Sumetra, Sulawesi, dan Kalimantan.

35 Dikutip dari akun Facebook resmi DPP HTI pada Minggu, (13/3/2016), pukul 06:03 WIB. 


\section{Daftar Pustaka}

Al-Makassary, Ridwan dan Ahmad Gaus AF, (ed). 2010. Benih-benih Islam Radikal di Masjid: Studi Kasus Jakarta dan Solo. Jakarta: CSRC UIN Jakarta.

DPP HTI. 2009. Manifesto Hizbut Tahrir untuk Indonesia: Indonesia, Khilafah dan Penyatuan Kembali Dunia Islam. Tanpa penulis: HTI.

Effendy, Bahtiar dan Handro Prasetyo (penyt.). 1998. Radikalisme Agama. Jakarta: PPIM-IAIN.

Effendy, Bahtiar dan Soetrisno Hadi (ed). 2007. Agama dan Radikalisme di Indonesia. Jakarta: Nuqtah.

Fealy, Greag. 2001. "Inside the Laskar Jihad: An Interview with the Leader of A New Radical and Militant Sect," Inside Indonesia, January-March: http: // www.insideindonesia.org/dit 71/fealy

Harto, Kasinyo. 2008. Islam Fundamentalis di Perguruan Tinggi Umum: Kasus Gerakan Keagamaan Mahasiswa Universitas Sriwijaya Palembang. Jakarta: Badan Litbang dan Diklat Departemen Agama RI.

Hasan, Noorhaidi. 2010 "Ideologi, Identitas dan politik Kekerasan: Mencari Model Solusi Mengatasi Ancaman Radikalisme dan Terorisme di Indonesia," Prisma, Vol. 29. LP3ES.

Jati, Wasisto Raharjo. 2013. "Permasalahan Implementasi Perda Syariah dalam Otonomi Daerah", al-Manahij, Vol. vii No.2 Juli.

Kompas, "Predator Nyata di Dunia Maya", Kompas (Kamis, 17 Desember 2015)

Muthohirin, Nafi'. 2014. Fundamentalisme Islam; Gerakan dan Tipologi Pemikiran Aktivis Dakwah Kampus. Jakarta: IndoStrategi.

Nashir, Haedar. 2013. Islam Syariat; Reproduksi Salafiyah Ideologis di Indonesia. Jakarta: Mizan dan Maarif Institute.

Reinhard Golose, Petrus. 2015. Invasi Terorisme ke Cyberspace. Jakarta: Yayasan Pengembangan Ilmu Kepolisian/YPKIK.

Roy, Olivier. 1994 The Failure of Political Islam. London: I.B. Tauris \& Co Ltd.

Said Damanik, Ali. 2002. Fenomena Partai Keadilan; Transformasi 20 Tahun Gerakan Tarbiyah di Indonesia, Jakarta: Teraju.

Tibi, Bassam. 1998. The Challange of Fundamentalism: Political Islam the New World Disorder. London: University of California Press.

Wahid, Abdurrahman (ed.). 2009. Ilusi Negara Islam: Ekspansi Gerakan Islam Transnasional di Indonesia. Jakarta: LibForAll Foundation.

Zada, Khamami. 2011. "Wajah Radikal Penerbitan Islam di Indonesia”, Indo-Islamika, Vol 1, No. 1. 